\title{
The Role of Political Culture in Shaping Canadian, EU and
}

\section{US Disarmament Initiatives}

\author{
Rouba Al-Fattal
}

\begin{abstract}
Canada and the European Union (EU) share, to a certain extent, a similar political culture, one based on multilateralism and the use of soft power. Nevertheless, over the past fifteen years Canada has been sometimes adopting disarmament policies that are similar to those of the EU and different from those of the US, while in other times it has been adopting policies that are similar to those of the US and different from those of the EU. This indicates that similarity in political culture alone is not sufficient enough to create convergence on foreign policies and that certain conditions must first be met for political culture to take precedence over neorealist explanations when dealing with security issues. Using Canadian, EU and US decisions on the issues of anti-personnel landmines and Iranian nuclear proliferation dilemma as case studies, this article analyses the conditions under which political culture plays a role in forming similar security policies.
\end{abstract}

\section{Key words: political culture; European Union; Canada, United States; nuclear proliferation; landmines}




\section{Introduction}

During the past decade there has been a growing dissatisfaction with using only neorealist approach in explaining foreign policies, and a growing interest in using also cultural arguments to explain international relations and security policies. "In the post-Cold War world," argues Huntington, "for the first time in history, global politics has become multipolar and multicivilizational." Accordingly, in the post-Cold War era "the most important distinctions among people are not ideological, political or economic. They are cultural...People define themselves in terms of ancestry, religion, language, history, values and customs.",2

Culture as a foreign policy indicator appeared promising in explaining some phenomena that neorealism alone can not explain. However, there are a number of interrelated cultural explanations which explore themes such as military, strategic, organizational, global and political culture from a different perspective than neorealism. This paper focuses on political culture variable (which will be defined in the next section) since, as John Duffield puts it, "Political culture promises to explain phenomena that are puzzling from the perspective of leading non-cultural theories, such as neorealism. Yet it is likely to apply to a broader range of cases than do the alternative cultural concepts that have been employed." 3 Also "political culture subsumes most alternative societal-level cultural constructs, such as strategic culture and military culture, while remaining focused on political phenomena in contrast to national character.",

This work treats the European Union (EU) as a whole, instead of providing analysis on particular European Union members. In doing so, (and for the sake of theoretical parsimony), the assumption that there is a common political culture at the EU level, at least with regards to the policies at hand, is maintained. This assumption stems from apparent increases in EU reliance on the role of the

\footnotetext{
${ }^{1}$ Samuel Huntington. The Clash of Civilizations and the Remaking of World Order. New York: Simon \& Schuster, 1997. p. 21

2 Ibid., p. 21

${ }^{3}$ John Duffield. "Political Culture and State Behavior: Why Germany Confounds Neorealism." International Organization. 53, no.4 (Autumn1999). p. 766

${ }^{4}$ Ibid., p. 777
} 
Common Foreign and Security Policy (CFSP) role in forming policy priorities for the two disarmament issues this work is based on: landmines and nuclear non-proliferation. In fact, not automatically but through intergovernmental cooperation and negotiations, the EU has reached a common response to those international issues at hand. Almost all EU members have adopted a similar position in the landmine case (Finland serves as an exception). And all EU members adopted a common position or a joint action in the case of Iran's nuclear policy. Additionally, there appears to be an emergence of talks about a unified EU political culture (at least among the older Western European member states, when these issues were peaking) which did not exist a decade ago. ${ }^{5}$

Notwithstanding the rising strength of political culture as a variable, helping to explain states behaviour in the post-Cold War period, the political cultural argument has also been criticized for its inability to explain some forms of state behavior, such as those that states adopt despite their obvious contradiction with their prevailing political culture. Thus, a deeper analysis may help reveal that in order for the political cultural variable to be a highly determining measure in explaining state behaviors, especially in international security domains, certain conditions need first to be met. Therefore, the question that this paper asks is: under which condition(s) does political culture play a leading role in shaping foreign and security policies of states or international bodies (such as the EU)?

Through inductive reasoning and interpretive case analysis, it appears that all three conditions need first to be simultaneously satisfied for political culture to count as the leading explanatory factor for states implementing certain security policies. First, the security issue which the state is dealing with needs to be perceived of as a low threat or risk issue. Thus, it must be perceived of (objectively or subjectively) as a threat solely to human and not a threat (whether directly or indirectly) to national security. Second, the public needs to be aware of the issue and be involved in the decision making process. Public opinion can be either manifested through strongly expressed views in the street or organized through Non-Governmental Organizations (NGOs) and civil society movements. Third, the

\footnotetext{
${ }^{5}$ Interview, Canadian Mission to the EU, Brussels, 2005
} 
political elite or policy makers, be it a group or an individual, which is involved in the decision making process must be an idealist, legacy seeker, charismatic actor or a firm believer in the issue as well as the political culture that is being represented. In other words the policy maker or political entrepreneur must represent and act on behalf of the political culture of the collective; and he must be able to influence public opinion on the matter. The author, hence, chooses to analyze these particular case studies (landmines and Iran's nuclear programme) and the corresponding policies that were adopted for them in Canada, the EU and the US to help illustrate the argument put forward. The case studies prove to correspond to the circumstances set up by the author. In fact, the two cases line up on all three aforementioned conditions but in a contradictory fashion. While in the landmines case all three conditions were present, in the case of Iran's nuclear programme they are all absent. This allows the author to demonstrate the necessity of all three conditions to be present in order for political culture to play a determinant role in foreign policy.

In order to illustrate the importance of these three conditions which allow political culture to matter in forming foreign policies, this article first turns to demonstrate that Western political culture has some important variations. So, contrary to Huntington who groups the West - Europe, Canada and the United States (US) - under one big cultural umbrella, ${ }^{6}$ the contemporary West in Wendt's opinion is composed of at least two forms of political cultures that correspond to two different levels of "cultural internalization."7 Accordingly, the US has a different political culture from that of Canada and the EU due largely to historical reasons. ${ }^{8}$ Thus, the US has a political culture of what Wendt would call a second degree level of internalization, ${ }^{9}$ focused on self interest, unilateralism and militarism. Canada and the EU, on the other hand, have a similar political culture, one of the third degree which emphasizes legitimization of actions, multilateralism and the use of soft-power (persuasion and

\footnotetext{
${ }^{6}$ Samuel Huntington. p. 46

${ }^{7}$ Alexander Wendt. Social Theory of International Politics. Cambridge: Cambridge University Press, 1999. p. 250,254

${ }^{8}$ Philip Resnick. The European Roots of Canadian Identity. Peterborough: Broadview Press, 2005. p. 8

${ }^{9}$ Alexander Wendt. p. 246-312
} 
diplomacy). ${ }^{10}$ Next, this article compares the actions (including ends and means) of Canada to that of the EU and the US regarding two different disarmament policies: banning personnel land mines and halting Iran's Uranium enrichment. The results of this research demonstrate that Canada converged with the EU but not the US when it came to the land mine issue and converged with the US but not the EU on the Iranian nuclear program. The differences between Canada and the EU on the question of Iran's nuclear Programme may be attributed to the fact that the three conditions, that were mentioned earlier, were all satisfied during the land mine situation but were not all met during the Iranian case. The fact that Canada and the EU acted similarly when it came to policies on banning landmines than on prohibiting Iran's nuclear ambitions-in spite of the political culture similarities between Canada and the EU and despite the political culture differences between Canada and the US-demonstrates that political culture on its own is not sufficient to explain foreign policies and that it needs to be looked at within a framework of the surrounding circumstances.

\section{Political culture: definition, debate and criticism}

Thomas Risse defines political culture as those "worldviews and principled ideas—values and norms - that are stable over long periods of time and are taken for granted by the vast majority of the population. Thus, the political culture as part of the domestic structure contains only those ideas that do not change often and about which there is societal consensus." ${ }^{11}$ And according to Duffield, political culture has been used as a term to emphasize the inter-subjective orientation of assumptions about the political world. These assumptions and perceptions of members of a particular society guide and inform their political actions. ${ }^{12}$ Generally speaking, political culture can be defined as "the sets of symbols and meanings or styles of actions that organize political claims-making and opinion-forming,

\footnotetext{
${ }^{10}$ Joseph Nye. Soft Power: The Means to Success in World Politics. New York: Public Affairs, 2005. p. 31, $78-79$

11 Thomas Risse-Kappen. "Ideas do not Float Freely: Transnational Coalitions, Domestic Structures, and the End of the Cold War.” International Organization. 48, no. 2 (Spring 1994). p. 209

12 John Duffield. p.774
} 
by individuals or collectives." 13 Thus, by political culture this author means political patterns of publicly shared symbols, meanings or style of actions which enables and constrains what elites and politicians can say or do or the actions that they may take.

There are three identifiable ways in which political culture can directly influence behavior of a collective; as such, political culture may help define the political goals of the group. Firstly, it can define the way a state or an institution perceives its interests and, in turn, the way they pursue policies that will insure these interests. Secondly, political culture can shape the group's perception of the external environment. As a result, the group pays particular attention to certain events and actions that challenge their political culture, while neglecting other which do not directly affect their identity. Finally, political culture may eliminate (or emphasizes) on certain actions. Therefore, some behaviors or policies become an impossible solution while others become viable options depending on the limits that political culture draws for the group. ${ }^{14}$

Applying political culture as an independent variable to account for security and foreign policies has been criticized for various reasons. One of these criticisms considers the study of the effect of political culture on states behavior as "ethnocentric," one that is not based on empirical evidence but on feeling or intuition. However, "these early criticisms were addressed through an increased use of more systemic techniques such as sample survey, quantitative content analysis, and structured interviews." Another common criticism is that cultural explanations are methods that scholars resort to whenever they are short of other explanations which are based on more concrete factors. This criticism does not flow from the inherit limitations of cultural variables but from the way they are deployed. Thus, scholars should not wait for other explanations to be exhausted before they resort to culture. On the contrary, they should consider it from the start, and define immediately the unit and the cultural form that they are going to use — be it institutional, global, military or political—and remove behavior

\footnotetext{
${ }^{13}$ Robert Goodin and Charles Tilly. Contextual Political Analysis. Oxford: Oxford University Press, 2006. p. 392

${ }^{14}$ Ibid., p. 772
} 
from their definition of culture to avoid tautology. Finally, the most frequent and serious criticism "concerns the difficulty of defining, operationalizing, and measuring cultural variables." Political culture has been criticized by many scholars—-such as Desch—for lacking a clear definition; however, one could object to this claim since Risse and Duffield seem to give a relatively clear definition of political culture. Although, it is not obvious what Risse believes to be a "long periods of time"; this author, for the purpose of this paper, will consider values that are stable for at least a decade to constitute a political culture. Also, Desch's criticism may apply to many other concepts, such as power which is used by neorealist and lacks a clear definition as well. Add to that, Desch who himself criticizes cultural approach concedes that "the definitional problem, however, is largely one of application rather than principle, because it is possible to clearly define and operationalize culture."15

The article now proceeds to compare the political culture and two disarmament policies concerning APMs and Iran proliferation of nuclear weapons in Canada, the EU and the US. In order to try and understand the factors that shaped decisions among these political communities, this author analyzes the conditions under which the policies were taken. By doing so, it will become evident whether political culture plays the role this author predicts it does, when all three conditions are present.

\section{Anti-Personnel Land Mines (APMs) Treaty}

The Ottawa Convention or Mine Ban Treaty is a formal "convention on the prohibition of the use, stockpiling, production and transfer of APMs and on their destruction."16 In September 1997, the treaty was open for signature in Oslo-Norway, and in March 1999 it entered into force. ${ }^{17}$ The International Campaign to Ban Land Mines (ICBL) 2006 report indicates that 154 countries signed the

\footnotetext{
${ }^{15}$ Ibid., p. 773

${ }^{16}$ David Long. "The European Union and the Ottawa Process to Ban on Landmines." Journal of European Public Policy. 9, no. 3 (June 2002). p. 429

${ }^{17}$ Canada Treaty Information. Ottawa Convention, 2006. Available online from http://www.treaty-accord.gc.ca/Details.asp?Treaty ID $=102758$
} 
treaty and 151 of them already ratified it, ${ }^{18}$ while 40 states have not yet signed it including the US. ${ }^{19}$ The report shows that Canada and almost all of the EU member states signed and ratified the treaty. ${ }^{20}$

In October 1996, Canada hosted the "Ottawa International Strategy Conference towards a Global Ban on APMs." ${ }^{21}$ NGO and representatives of 71 states attended the conference, ${ }^{22}$ The highlight of the conference occurred during the closing ceremonies when Canada's (then) Foreign Minister, Lloyd Axworthy, surprised and challenged states delegates in his closing speech, by asking them to meet within a year to sign a Mine Ban Treaty. Fortunately, the continuous negotiations and meetings between Mr. Axworthy and Foreign Ministers of various countries over the whole year after the Conference were not in vain, because by December 1997122 out of the 150 states who had attended the Ottawa Convention have signed the treaty during the event. ${ }^{23}$

According to the 2005 Landmine Monitor Report, 84 states and 8 territories had been identified as affected "to some degree by landmines and/or unexploded ordinance (UXO), of which 54 are State Parties to the Mine Ban Treaty;"24 Since 2003 the Bosnia and Herzegovina Mine Action Center (BHMAC) has recorded in Bosnia and Herzegovina $(\mathrm{BiH})$ alone the existence of still 18,600 landmines, despite all the constant de-mining efforts. ${ }^{25}$ Most of these mines lie along the deserted front lines where opposing ethnic enemies fought the Bosnian-Serbian War (1992-1995), "covering approximately $4.4 \%$ of the total landmass of BiH." 26 They were dropped by North Atlantic Treaty Organization (NATO) air-fighters when its troops intervened to stop the Serbian aggression in

\footnotetext{
${ }^{18}$ International Campaign to Ban Landmines. States Parties, 2006. Available online from http://www.icbl.org/treaty/members

${ }^{19}$ International Campaign to Ban Landmines. States not Parties, 2006. Available online from http://www.icbl.org/treaty/snp

${ }^{20}$ Ibid.

${ }^{21}$ David Lenarcic. Knight-Errant? Canada and the Crusade to Ban Anti-Personnel Land Mines. Toronto: Irwin Publishing, 1998. p. 11

22 Ibid.

${ }^{23}$ Canada's Department of Foreign Affairs. Canada's Guide to the Global Ban on Landmines: The International Movement to Ban Landmines-Ottawa Convention Signing Conference and Mine Action Forum, 1997. Available online from http://www.mines.gc.ca/II/II_D-en.asp

${ }^{24}$ International Campaign to Ban Landmines. Landmine Monitor Report: Major Findings, 2005. Available online from http://www.icbl.org/lm/2005/

${ }^{25}$ International Campaign to Ban Landmines. Landmine Monitor Report: Bosnia-Landmine and UXO Problem, 2005. Available online from http://www.icbl.org/lm/2005/bosnia.html\#Heading59

${ }^{26}$ Ibid.
} 
December $1995 .{ }^{27}$ According to an interview conducted with an expert on the issue, the number of landmines could be higher than reported; no one knows precisely how many mines were buried but went unrecorded. ${ }^{28}$

Realizing the urgency and gravity of the situation, Canada and the EU with the help of various NGOs mobilized quickly to deal with this dreadful human security condition. ${ }^{29}$ They pursued policies, which were in accordance with their political culture and their aspiration to promote human security globally through multilateral cooperation, despite the huge economic cost that they knew they would incur for this mission. Actually, at the time the United Nations (UN) estimated that the cost of removing all the active landmines will accumulate to US \$33 billion and will take many years to accomplish. $^{30}$ Canada and the EU still joined in this international campaign that would not only prohibit them from the use, transfer and production of APMs, but that would also require them to destroy their stockpile of it and provide humanitarian assistance and rehabilitation programs to landmines victims. ${ }^{31}$ Canada's Prime Minister in 1998-Jean Chrétien-in order to help "universalize the land mines convention and allow it to achieve its humanitarian objectives," allocated CAN \$100 million for this cause over a period of five years, which was renewed for CAN \$72 million for another five years (2003-2008). ${ }^{32}$ At the same time the EU allocated $€ 60$ million of its budget, which would be renewable over a period of two years. Nonetheless, the estimate of total EU assistance for mine action during 2005-2007 surmounts to $€ 140$ million. $^{33}$

It is worth noting here that the US response to the Ban Landmines Treaty was different from that of its Western allies. It was not because there was a lack of public support for the treaty; in fact,

\footnotetext{
${ }^{27}$ Rae McGrath. Landmines and Unexploded Ordnance: A Resource Book. London: Pluto Press, 2000. p. 42, 195, 135-136

${ }^{28}$ Interview, Center for Defence Information (CDI), Brussels, 2005

${ }^{29}$ Cameron Maxwell, et al. To Walk without Fear: The Global Movement to Ban Landmines. New York: Oxford University Press, 1998. p. 32, 34, 40-41

${ }^{30}$ David Lenarcic. p. 3

${ }^{31}$ Canada's Department of Foreign Affairs. Canada's Guide to the Global Ban on Landmines: Canada's Support for Mine Action, 2006. Available online from http://www.mines.gc.ca/menu-en.asp

${ }^{32}$ Ibid.

${ }^{33}$ European Commission External Relations. European Union and Anti-Personnel Landmines Challenge: EU Mine Action Strategy 2005-2007, 2004. Available online from http://ec.europa.eu/comm/external_relations/mine/intro/strat05_07.htm
} 
several American NGOs pushed for it. ${ }^{34}$ They did not sign it because the US owns the biggest stockpile of these weapons. Indeed, it is also the main producer and user of landmines. Most importantly, why it did not want to sign, because it does not want to clear its stockpile from North Korea or not be able to use them if necessary in that region. ${ }^{35}$ In fact, the US wanted to take part in the treaty, especially when it sensed that it was being left out of the initiative, ${ }^{36}$ but the international community could not convince it to bend on the North Korea exception. Consequently, Canada and the EU signed a comprehensive treaty, while US national security and realist considerations took precedence over humanitarian security. In the end, the US acted according to its political culture, which is generally self regarding, and did not sign the treaty. ${ }^{37}$

\section{Analysis of the Landmine case in light of political culture conditions}

The Canadian, EU and US responses to the landmine issue demonstrates how political culture can play a significant role and shaped these entities' foreign policies. Clearly, Canadian and EU's general preference for multilateralism and their concern about human security distinguishes them from the US and makes them sign humanitarian agreements, like the Ottawa Convention, when the US does not. However, political culture on its own does not account for the EU and the Canadian response. So, now in order to prove this point the article will go on to discuss in detail the three conditions which made political culture matter.

The first condition stresses that the security issue affecting the state needs to be perceived of as a low threat one. Clearly, APMs are considered a low risk issue for Canada and the EU because it poses a threat to human security but not to a national one. And yet, it is important enough from a humanitarian perspective. The speech of Jean Chrétien, Canada's Prime Minister, at the treaty signing

\footnotetext{
${ }^{34}$ Cameron Maxwell. p. 22, 100

${ }^{35}$ David Lenarcic. p. 25-26

${ }^{36}$ Ibid.

${ }^{37}$ Rae McGrath. p. 8
} 
conference in 1997, emphasized that land mines are a human security concern more than anything else. ${ }^{38}$ Still, landmines in less developed countries are not considered a direct menace to Canada's or EU's survival and peace. And, there are no landmines in Canada or in EU member states to worry about; so, political culture and moral considerations can have the upper hand in this situation. ${ }^{39}$ Also, there was no ambiguity or uncertainty in the objectives behind this policy; negotiations on land mines had a relatively transparent character. ${ }^{40}$

The second condition emphasizes that public opinion has to be involved in the decision making process. Certainly, public attention to this grim issue was grasped not only by the statistics but also by the testimonies of landmine victims, who survived to tell their stories. ${ }^{41}$ These victims got involved with important organizations, such as Landmines Survivors Network, and their stories were picked up by the media and received words of sympathy from the Pope John Paul II and celebrities like Princes Diana. ${ }^{42}$ Public pressure to get something done on landmines was, and still is, very prominent; ICRC, ICBL, Mine Action Canada (MAC), are among few of the organizations that are working diligently to eliminate this perfidious weapon and the suffering that is associated with it. ${ }^{43}$ Generally, on the government side there is some hostility towards NGOs. ${ }^{44}$ Many politicians are irritated by NGOs taking their position on decision making, when politician consider themselves to be elected representatives of the people and thus better at judging what the people want. ${ }^{45}$ Hence, there seems to be "a mutual agreement between NGOs and the government to keep a distance, operate in different spheres and intersect only on specific issues." 46 Luckily, on the landmines issue Canadian Foreign Affairs officials

\footnotetext{
${ }^{38}$ Canadian Government Library and Archives. Jean Chrétien Speech at the Treaty signing conference, 1997. Available online from http://www.collectionscanada.ca/primeministers/h4-4081-e.html

${ }^{39}$ United Nations Mine Action Service (UNMAS). Video: If There Were Landmines Here, Would You Stand for Them Anywhere?, 2006. Available online from http://www.stoplandmines.org/slm/index.html

${ }^{40}$ David Long. p. 442

${ }^{41}$ Lloyd Axworthy. Navigating a New World: Canada's Global Future. Toronto: Vintage Canada, 2004. p. 130

42 Ibid.

${ }^{43}$ Cameron Maxwell. p. 163, 168, 173, 176, 180

${ }^{44}$ Lloyd Axworthy. p. 139

${ }^{45}$ Ibid.

${ }^{46}$ Ibid.
} 
"rewrote the script" in cooperating with NGOs and accepting their advice. ${ }^{47}$ For instance, in his speeches Minister Axworthy quoted Red Cross doctors-who deal with treating landmines civilian victims, especially children-saying that the "worst results are not physical. The most serious consequence was psychological trauma, the aftermath of being suddenly mutilated, of having their lives drastically changed for no reason. This required careful and often prolonged counseling." 48 Indeed, there is a huge number of NGOs that got involved and pushed the US, Canada and EU member states to sign the ban-land mines treaty. ${ }^{49}$ However, NGOs did not succeed in the US because landmines for the US are a national security matter since it involves North Korea, and generally the US follows its interests more than international norms. However, even without the US's support the treaty was signed after a year of negotiations only, which makes it one of the fastest treaties to be signed and ratified due to NGOs and public intense involvement. ${ }^{50}$

The third condition focuses on the role of the leader in setting the agenda and pushing for the policy. The political entrepreneur who took the leading role on the APMs treaty was definitely the Canadian Minister of Foreign Affairs in 1996 under the Liberal Party, Axworthy. ${ }^{51}$ He is a known idealist who is also a firm believer in Canada's multilateralism and soft power traditions. ${ }^{52}$ In his book he says that his own resolve was certainly strengthened when he could not find an acceptable answer to his young son's question, who asked him, while they were touring a landmine exhibition, "why would any one use such weapons to kill children?"53 No doubt that Axworthy's leadership ability granted the success of the Ottawa Convention and his nomination in 1997 to receive the Nobel Peace Prize for his

${ }^{47}$ Ibid.

${ }^{48}$ Ibid., p. 131

${ }^{49}$ Richard Matthew, Bryan McDonald, and Kenneth Rutherford. Landmines and Human Security: International Politics and War's Hidden Legacy. New York: State University Press, 2004. p. 6

${ }^{50}$ Canada's Department of Foreign Affairs. Canada's Guide to the Global Ban on Landmines: The International Movement to Ban Landmines-Ottawa Convention Signing Conference and Mine Action Forum, $1997 . \quad$ Available online from http://www.mines.gc.ca/II/II_D-en.asp

${ }^{51}$ Canada's Department of Foreign Affairs. Canada's Guide to the Global Ban on Landmines: Documents and Research Materials-Judy Williams Speech, 1997. Available online from http://www.mines.gc.ca/VII/VII_A_xi_c_2-en.asp

${ }_{53}^{52}$ Lloyd Axworthy. p. 1-2

${ }^{53}$ Ibid., p. 136 
work on banning landmines, which he did not get but was thanked by the recipient_- ICBL_-speaks for his outstanding role in banning landmines. ${ }^{54}$ Axworthy worked very hard to convince Canadian Defence Ministry to get rid of Canada's landmines stockpile. ${ }^{55}$ On the day of the_Ottawa International Strategy Conference towards a Global Ban on APMs, in 1996, and just before the Conference started, Axworthy met with officials from his cabinet and with some important NGOs representatives. He confesses (later in his book) that no one new if the Conference and his initiative to call on countries to sign the Treaty within a year will succeed but they were all willing to give it a go. At that moment he "realized that the decision was in his hands alone and he said it's the right thing. Let's do it.",56 Axworthy's decision to take the lead, and his incredible political will was fruitful. The Canadian initiative shifted the movement on land mines from Geneva to Ottawa and made the Ottawa Convention a Canadian as well as a humanitarian legacy. ${ }^{57}$

\section{Iran's nuclear proliferation program}

In 1968 Iran signed the Nuclear non-Proliferation Treaty (NPT), which entered into force in $1970 .^{58}$ This legally binding treaty obligates five nuclear-weapon states (Britain, China, France, Russia, and the US) to disarm and prohibits the ratifying states from pursuing proliferation of Weapons of Mass Destruction (WMD). ${ }^{59}$ Nevertheless, Article 4 of the NPT allows parties to engage in peaceful nuclear programs, such as the production of nuclear energy for domestic use, as long as they are under the International Atomic Energy Agency (IAEA) safeguard. ${ }^{60}$ For years, Iran concealed the fact that it

\footnotetext{
${ }^{54}$ David Lenarcic. p. 64

${ }^{55}$ Lloyd Axworthy. p. 133

56 Ibid., p. 137

${ }^{57}$ Ibid., p. 134-135

${ }^{58}$ Canada Treaty Information. Treaty on the Non-Proliferation of Nuclear Weapons, 2006. Available online from http://www.treaty-accord.gc.ca/Details.asp?Treaty_ID=103576

${ }^{59}$ Canada's Department of Foreign Affairs and International Trade. Introduction to the Treaty on the Non- Proliferation of Nuclear Weapons (NPT), 2006. Available online from http://www.dfait-maeci.gc.ca/arms/intro-nuclear-treaty-en.asp

${ }^{60}$ International Atomic Energy Agency (IAEA). In Focus IAEA and Iran: Iran Safeguards Agreement, 1974. Available online from http://www.iaea.org/NewsCenter/Focus/IaeaIran/index.shtml
} 
was building Uranium enrichment facilities. Suddenly in August 2002, an Iranian opposition activist, Alireza Jafarzadeh, revealed the existence of two unknown nuclear sites in Natanz and Arak. ${ }^{61}$ This discovery created tension between Iran and the West and Iran's nuclear activities became scrutinized and feared by the US, Europe and Canada. ${ }^{62}$

Despite the repetitive verbal assurances by Iranian officials, Western governments remain greatly concerned that Iran is using its civilian nuclear programme to mask an undeclared military nuclear agenda for several reasons. Firstly, Iran's radical Islamic views and its overt (moral or material) support to anti-Western "terrorist" organization such as Hezbollah raise many red flags in the West. ${ }^{63}$ In fact, David Harris, a former agent with Canadian Security and Intelligence Service (CSIS) remind us that "Ahmadinejad has also called Israel a disgraceful stain on the Islamic world and has vowed to have Israel wiped off the map." ${ }^{64}$ So, although Iran now is stressing its commitment to the NPT, the fear is that once it develops nuclear weapons it will act like North Korea and abandon the treaty and sell its knowledge to rogue states and terrorist organization. ${ }^{65}$ These intentions were presented in Khamenei's statement that Iran is "prepared to transfer the experience, knowledge and technology of its nuclear scientists. ${ }^{\prime 66}$ Hence, the West views the verbal assurances by Iranian officials and supreme religious leaders as time buying mechanisms that will change once Iran acquires nuclear defence capabilities. Second, Iran's lack of transparency, its failure to report to the IAEA the construction of nuclear facilities and its pursuit of nuclear technology covertly for 18 years have fuelled suspicion in the West

\footnotetext{
${ }^{61}$ Strategic Policy Consulting (SPC). Biography: Alireza Jafarzadeh, 2005. Available online from http://www.spcwashington.com/index.php?option=com_content\&task=view\&id=32\&Itemid=43

${ }^{62}$ European Union Institute for Security Studies (EU-ISS). Newsletters no. 19: dialogue with Iran-the EU Way out of the Impasse, 2006. Available online from http://www.iss-eu.org/newslttr/n19.pdf

${ }^{63}$ Center for Strategic and International Studies (CSIS). Publications-Iran: Iran's support of the Hezbollah in Lebanon, 2006. Available online from http://www.csis.org/component/option,com_csis_pubs/task,view/id,3360/

64 Ibid.

${ }^{65}$ New Threat Initiative (NIT). Issue and analysis: Iran, 2004. Available online from http://www.nti.org/e research/e3 59a.html

${ }^{66}$ Institute for Science and International Security (ISIS). Publication-Iran: Better Carrots not Centrifuges, 2006. Available online from http://www.isis-online.org/publications/iran/iranissuebrief.pdf
} 
that Iran's nuclear programme has a "military dimension" to it. ${ }^{67}$ Indeed, in February 2006, ElBaradei reported that the Agency has not seen clear indications of deviation of nuclear material to nuclear weapons; however, he also noted that there was a lack of cooperation and transparency from the Iranian side over the past three years of dealings with the IAEA, ${ }^{68}$ which created, according to may Western analysts, a "confidence deficit" regarding Iran's intentions. ${ }^{69}$ Third, many governments, including the US, the EU and Canada, do not understand Iran's insistence on acquiring the 'know how' of nuclear technology, and enriching Uranium on its soil if it was only for civilian use. Actually, one of the alternatives or "carrots" that was proposed by the E3/EU and refused by Iran in 2004 was for the EU to provide all necessary civilian nuclear energy to Iran, as long as the latter agreed to suspend all its nuclear activities. ${ }^{70}$ In addition, the West claims that Iran does not need nuclear power due to the fact that it has the third largest oil reserve in the world, and that nuclear power is more expensive for the Iranians to generate than oil-fired power. ${ }^{71}$ However, Iran's Oil Ministry Deputy for International Affairs, Hadi Nejad-Hosseinian, argues otherwise, insisting that at the current rate of oil production (which is 1.5 billion barrel a year), Iran's reserve (of 133.3 billion barrels) will deplete within 90 years, ${ }^{72}$ and Iran does not want to be dependent on others for its domestic energy in the future. ${ }^{73}$ Lastly, an assessment made by the International Institute for Strategic Studies (IISS) in 2005 concluded that "if Iran threw caution to the wind, and sought a nuclear weapon capability as quickly as possible without regard for international reaction, it might be able to produce enough Highly Enriched Uranium (HEU)

\footnotetext{
${ }^{67}$ International Atomic Energy Agency (IAEA). In Focus IAEA and Iran: Documents and Reports-February Resolution, 2006. Available online from http://www.iaea.org/NewsCenter/Focus/IaeaIran/index.shtml

${ }^{68}$ Ibid.

${ }^{69}$ European Policy Center (EPC). Iran's Nuclear Programme-a transatlantic assessment, 2006. Available online from http://www.theepc.be/en/er.asp?TYP=ER\&LV=293\&see=y\&t=2\&PG=ER/EN/detail \&l=\&AI=582

${ }^{70}$ New Threat Initiative (NIT). Nuclear Chronology: Iran, 2004. Available online from http://www.nti.org/e_research/profiles/Iran/1825_4398.html

${ }^{71}$ Central Intelligence Agency (CIA). The world Factbook: Iran, 2006. Available online from https://www.cia.gov/cia/publications/factbook/geos/ir.html

72 Alexander's Gas and Oil Connections. News: Iran May run out of Oil in 90 Years, 2005. Available online from http://www.gasandoil.com/goc/news/ntm54300.htm

${ }^{73}$ BBC News. Analysis: Iran's Nuclear Fuel Debate, 2006. Available online from http://news.bbc.co.uk/2/hi/middle_east/5235732.stm
} 
for a single nuclear weapon by the end of this decade. ${ }^{74}$ Furthermore, in June $2^{\text {nd }} 2006$ US Director of National Intelligence, John Negroponte, estimated that Iran, if left unchecked, could build a nuclear bomb between 2010 and $2015 .^{75}$

The possibility of Iran developing a nuclear weapons, or even knowing how to, causes a great concern in the West since it poses a "threat to the stability in the Middle East," which is strategically very important for the West to maintain. ${ }^{76}$ So, Canada, the EU and the US appear to view these ambitions as an imminent threat to their national security and deem it a fatal situation. For that reason they all agree that they cannot allow Iran to continue with its Uranium enrichment program. ${ }^{77}$ However, when it comes to Iran, despite the fact that the West shares the same views/goals its entities do not seem to agree on the means to achieve these ends. The US has been pressuring the UN Security Council and the EU to enforce stronger sanctions against Iran while the EU keeps pushing for diplomacy, negotiations and mitigated sanctions. ${ }^{78}$

When Iran's nuclear activity was discovered in 2002, Canada appeared to err on the side of caution by not stating openly its unconditional support for the US regarding Iran's nuclear problem. In fact, at first it was hard to infer clearly from officials' statements whether Canada was on the EU's side (diplomacy) or on the US's side (sanctions). However, since 2003 as time went by under the liberal party-and continuing with the appointment of a Canadian Prime Minister (Stephen Harper) who represents the conservative party and seems to be pro-American-it looks like, on the Iranian issue, Canada has succumbed completely to the will of the US and is now swimming with their current and echoing their voice. This continuity in the reaction against Iran's nuclear program, under both liberal

\footnotetext{
${ }^{74}$ International Institution for Strategic Studies (IISS). Iran's Strategic Weapons Programmes—a net assessment, 2005. Available online from http://www.iiss.org/index.asp?pgid=5498

${ }^{75}$ BBC News. Middle East News: Iran Bomb within 10 Years, 2006. Available online from http://news.bbc.co.uk/2/hi/middle_east/5039956.stm

${ }^{76}$ European Policy Center (EPC). Iran's Nuclear Programme-a transatlantic assessment, 2006. Available online from http://www.theepc.be/en/er.asp?TYP=ER\&LV=293\&see=y\&t=2\&PG=ER/EN/detail\&l=\&AI=582

${ }_{77}$ Public conference: European Policy Center (EPC), Q/A period, Iran's Nuclear Programme-a transatlantic assessment, Brussels, 2006

${ }^{78}$ United Nations Department of Disarmament (UNDD). Disarmament Digest: Peace and Security through Disarmament, 2006. Available online from http://disarmament.un.org
} 
and conservative parties, indicates that partisan politics is not what is affecting Canada's response.

Instead, Canada's behavior is affected by the non-satisfaction of the three conditions which are needed

for political culture to play a role in foreign policy. One only has to read the official statement of Mackay, the current Canadian Foreign Minister, after the UN Security Council 1696 Resolution on 31

July, 2006 on Iran's nuclear program, to realize how Canada is bandwagoning completely with the US:

Canada fully supports the Resolution issued today by the UNSC, reiterating the international community's serious concerns about Iran's past and ongoing nuclear activities... It also notes Iran's failure to comply with the measures demanded of it in the UNSC Presidential Statement of March 29, 2006, as well as in various International IAEA Board of Governors Resolutions...Through this Resolution, the UNSC has made the suspension of Iran's enrichment and reprocessing activities mandatory. Canada urges Iran to implement this suspension immediately and to enter into negotiations toward a long-term comprehensive settlement, on the basis of the proposal offered on June 6 by the EU High Representative on behalf of China, France, Germany, Russia, the United Kingdom and the United States...Canada also supports the UNSC's determination to reinforce the authority of the IAEA in order to resolve all outstanding issues pertaining to the nature and scope of Iran's nuclear program. Canada urges Iran to cooperate fully with the IAEA, including through resumed application of the Additional Protocol to its Comprehensive Safeguards Agreement, as a necessary step toward a long-term comprehensive settlement. ${ }^{79}$

\section{Analysis of the Iran issue in light of political culture conditions}

By using the Iranian nuclear proliferation issue as a case study, the author tries to demonstrate how Canadian material interests were given precedence over Canada's political culture regarding this problem. Canada, the EU and the US in this case all have similar fears and goal, which is to stop Iran's Uranium enrichment program, nevertheless they use different means to achieve this goal. In dealing with Iran the EU follows to a certain degree its norms and political culture, and hence it prefers the use of diplomacy and persuasion. The US follows its interests and political culture, and so it favors sanctions and use of force (or threatening language). While Canada in this case does not follow its political culture but considers its strategic interests and thus it bandwagons with the US, abandoning its soft power tradition in the adopting of the US's hard power rhetoric. The reason behind this Canadian

\footnotetext{
${ }^{79}$ Canada's Department of Foreign Affairs and International Trade. News Releases: Statement by MinisterMackay on UNSC Resolution on Iran's Nuclear Program, 2006. Available online from http://w01.international.gc.ca/minpub/Publication.asp?publication_id=384286\&Language=E
} 
behavior, is that the three conditions-which are essential to be all satisfied in order for political culture to play the main role in shaping foreign policies - are absent in the Iranian situation. In order to demonstrate this point, the article will go on to discuss those three conditions and their effects in detail.

The first condition stresses that the security issue which the state is dealing with needs to be perceived of as a low threat one. This is obviously not the situation here since the Iranian problem poses a threat to national security and to the survival of the state (although not in the direct sense). Iran's nuclear ambitions are of great concern to the West; not only because Iran's purposes for insisting on enriching Uranium on their soil is ambiguous to the West, but also because Iran's previous policies and statements have had aggressive tendencies and tones towards the West. Canada, the EU and the US seem to be uncertain that the Iranian government would act responsibly and refrain from the use of nuclear weapons in order to advance some of their Islamic fundamentalist goals. ${ }^{80}$ The fear of Iran's advanced nuclear program and its intentions to develop nuclear weapons in the future is not new. In a joint declaration released on June 3 2003, the G-8 nations-Canada, France, Germany, Italy, Japan, Russia, the United Kingdom and the US — harshly criticized Iran's lack of transparency and its failure to abide by its IAEA safeguards agreement. According to the G8 "such actions undermine the nonproliferation regime and are a clear breach." The G8 also said "We recognize that the proliferation of WMD and their means of delivery pose a growing danger to us all. Together with the spread of international terrorism, it is the pre-eminent threat to international security." ${ }^{81}$ Canada in particular expressed its great concern about Iran's nuclear program in its statement to the $47^{\text {th }}$ General Conference of the IAEA on 16-17 September $2003 .^{82}$

\footnotetext{
${ }^{80}$ Public conference: European Policy Center (EPC), Q/A period, Iran's Nuclear Programme-a transatlantic assessment, Brussels, 2006

${ }^{81}$ New Threat Initiative (NIT). Nuclear Weapons: G8 Declaration on Iran Nuclear Program, 2003. Available online from http://www.nti.org/d_newswire/issues/newswires/2003 6 3.html

${ }^{82}$ Conference of Radiation Control Program Directors (CRCPD). 47th General Conference of the IAEA: Canadian Statement, 2003. p. 2. Available online from http://www.crcpd.org/International_IssuesTopics/IAEA2003/Canada.pdf\#search=\%22 canada\%2C\%20iran\%2C $\% 20$ nuclear $\% 2 \mathrm{C} \% 20$ proliferation $\% 2 \mathrm{C} \% 20$ security $\% 2 \mathrm{C} \% 20$ threat $\% 22$
} 
The second condition emphasizes that public opinion has to be involved in the decision making process. On the Iranian nuclear proliferation topic, public pressure-whether organized through open demonstrations or through NGOs_-is absent in Canada the EU and the US. The subject has been discussed for more than three years solely through high level officials. Civil society appears to agree with their respective governments on the problem and the solutions. However, the absence of civic participation might also be due to the lack of government's transparency on the topic_-which usually tends to alienate citizens and creates apathetic feeling towards the issue-or it may be due to the fact that the horrific effects of using nuclear weapons are not as tangible on a daily basis, as the consequences of using other conventional weapons.

The third condition focuses on the role of the leader in acting on behalf of his collective identity and pushing for the policies that would advance his countries political culture. For the EU, Solana seems to be the main political figure dealing with Iran's nuclear file and he has been trying hard to calm down the rising conflict between the US and Iran. For instance, on Wednesday August 30, 2006, the Financial Times published an article which stated that Solana is "ready to continue discussions with Iran over its nuclear programme even though a UN deadline for Tehran to restrict its nuclear activities expires on Thursday." ${ }^{83}$ As far as the US is concerned, it is President Bush who has been lobbying very strongly against enrichment. For example, in an article which was published on August 31 2006, also by the Financial Times, US President George W. Bush announced that Iran had to face the outcomes for its "failure to meet a UN deadline to halt its nuclear activities. "We must not allow Iran to develop a nuclear weapon. There must be consequences for Iran's defiance" Mr. Bush said, in a statement “seemingly intended to build international support for sanctions on Tehran." However, his incendiary towards such measures "has been undermined by Russia and China's continued resistance to

\footnotetext{
${ }^{83}$ Financial Times. EU Will Continue Nuclear Talks with Tehran, 2006 Available online from http://www.ft.com/cms/s/90a61514-3853-11db-ae2c-0000779e2340.html
} 
sanctions. $"{ }^{84}$ Conversely, in Canada there is obviously a Canadian leadership deficiency when it comes to Iran. Certainly, it looks like there is a growing rift between Canada's foreign policies on Iran (among other issues) and Canada's political culture, especially since Harper came to office in 2006. Moreover, Canadian Liberal and Conservative party officials—like Martin, Harper, Pettigrew and Mackay—seem to lack charisma, experience or popularity. For instance, looking at the national poles suggests that the public mistrusts these leaders' actions or motives, at one point or another during their term in office. Unlike Axworthy who possessed all three qualities before getting involved in the landmine issue, these leaders are either young and new to Foreign Affairs at the time when they had to deal with the Iranian issue (like Mackay). Or they lack charisma and popularity, as can be observed from the results of the Angus Reid Global Monitor Poll, in 2007, on Harper. Apparently, "fewer Canadians are satisfied with their prime minister... and 28 per cent say their opinion of the head of government worsened over the past months. ${ }^{, 85}$ However, as stated earlier, trust in a leader and his popularity are necessary leadership qualities, without which it becomes hard for a leader to consolidate his countries political culture into concrete policies that he can convince his people, his government and other governments to adopt.

\section{Conclusion}

Despite the attractiveness and popularity of neorealism as an explanation of state decisions in international politics, in the post-Cold War period it faces some severe challenges in providing an adequate accounting for many aspects of state security considerations. At times, states seem to be adopting policies that are not in their best interests (from a neorealist account) but more in accordance with their political culture, while at other time the opposite is true. Therefore, one must think that

\footnotetext{
${ }^{84}$ Financial Times. US Says Iran Must Face Consequences, 2006 Available online from http://www.ft.com/cms/s/95b60d46-3909-11db-a21d-0000779e2340.html

${ }^{85}$ Angus Reid Global Monitor: Polls \& Research. Harper Falls to 29\% in Canada, 2007 Available online From http://www.angus-reid.com/polls/index.cfm/fuseaction/viewItem/itemID/16582
} 
certain circumstances must be ripe for one approach to be more employable than the other, in order to account for this policy alteration. This article addressed the conditions under which the political culture approach can be used as an alternative to neorealism in order to explain security policies in the West.

The article commenced by demonstrating the similarities between Canadian and EU political cultures, while revealing important differences between Canada and the EU on one hand and the US on the other. For instance, Canada and the EU prefer multilateralism and the use of soft power, and the US prefers unilateralism and the use of hard power. This work then utilised two case studies which dealt with disarmament policies - anti-personnel land mines and Iranian nuclear proliferation - to illustrate that despite political culture similarities between Canada and the EU, they have adopted different paths when they tackled each issue. This again proves that political culture alone is not sufficient for two entities to have similar security policies, and that certain conditions need to be first satisfied in order for political culture to matter in forming foreign policies.

The article argues that three conditions need to be satisfied simultaneously for political culture to count as an explanatory factor for states implementing certain security policies. First, the security issue which the state is dealing with needs to be perceived of as a low security threat. Second, the public needs to be aware and involved in the matter. Third, the political elite who is involved in the policy making process must be an idealist and a firm believer in the political culture that he represents.

Finally, by using the two case studies the article manages to demonstrate how these conditions were present in the landmines case and absent in the Iranian one. The analysis of the case studies suggests that when the three aforementioned conditions are all present, political culture can be used as a viable supplementary to neorealism. Thus, both political culture and neorealism are, independently, unable to provide a wholly convincing account of state decisions over the paths and priorities in foreign affairs. A new balance must be struck which incorporates these theories (among others) to produce a more realistic account of international politics today. 


\section{Bibliography}

Alexander's Gas and Oil Connections. News: Iran May run out of Oil in 90 Years, 2005. Available online from http://www.gasandoil.com/goc/news/ntm54300.htm

Angus Reid Global Monitor: Polls \& Research. Harper Falls to 29\% in Canada, 2007 Available online From http://www.angus-reid.com/polls/index.cfm/fuseaction/viewItem/itemID/16582

Axworthy, Lloyd. Navigating a New World: Canada's Global Future. Toronto: Vintage Canada, 2004

BBC News. Analysis: Iran's Nuclear Fuel Debate, 2006. Available online from http://news.bbc.co.uk/2/hi/middle_east/5235732.stm

------. Middle East News: Iran Bomb within 10 Years, 2006. Available online from http://news.bbc.co.uk/2/hi/middle_east/5039956.stm

Canada Treaty Information. Ottawa Convention, 2006. Available online from http://www.treatyaccord.gc.ca/Details.asp?Treaty_ID $=102758$

------. Treaty on the Non-Proliferation of Nuclear Weapons, 2006. Available online from http://www.treaty-accord.gc.ca/Details.asp?Treaty_ID=103576

Canada's Department of Foreign Affairs. Canada's Guide to the Global Ban on Landmines: Canada's Support for Mine Action, 2006. Available online from http://www.mines.gc.ca/menu-en.asp

-------. Canada's Guide to the Global Ban on Landmines: Documents and Research Materials- Judy Williams Speech, 1997. Available online from http://www.mines.gc.ca/VII/VII_A_xi_c_2$\underline{\text { en.asp }}$

------. Canada's Guide to the Global Ban on Landmines: The International Movement to Ban Landmines-Ottawa Convention Signing Conference and Mine Action Forum, 1997.

Available online from http://www.mines.gc.ca/II/II D-en.asp

Canada's Department of Foreign Affairs and International Trade. Introduction to the Treaty on the Non-Proliferation of Nuclear Weapons (NPT), 2006. Available online from http://www.dfaitmaeci.gc.ca/arms/intro-nuclear-treaty-en.asp

-------. News Releases: Statement by MinisterMackay on UNSC Resolution on Iran's Nuclear Program, 2006. Available online from http://w01.international.gc.ca/minpub/Publication.asp?publication_id=384286\&Language=E

Canadian Government Library and Archives. Jean Chrétien Speech at the Treaty signing conference, 1997. Available online from _http://www.collectionscanada.ca/primeministers/h4-4081-e.html

Center for Strategic and International Studies (CSIS). Publications-Iran: Iran's support of the Hezbollah in Lebanon, 2006. Available online from http://www.csis.org/component/option,com_csis_pubs/task,view/id,3360/

Central Intelligence Agency (CIA). The world Factbook: Iran, 2006. Available online from https://www.cia.gov/cia/publications/factbook/geos/ir.html

Conference of Radiation Control Program Directors (CRCPD). 47th General Conference of the IAEA: Canadian Statement, 2003. Available online from 
http://www.crcpd.org/International_Issues-Topics/IAEA2003/Canada.pdf\#search=\%22 canada\%2C\%20iran\%2C\%20nuclear\%2C\%20proli feration $\% 2 \mathrm{C} \% 20$ security $\% 2 \mathrm{C} \% 20$ threat $\% 22$

Duffield, John. "Political Culture and State Behavior: Why Germany Confounds Neorealism." International Organization. 53, no.4 (Autumn 1999): 765-803

European Commission External Relations. European Union and Anti-Personnel Landmines

Challenge: EU Mine Action Strategy 2005-2007, 2004. Available online from http://ec.europa.eu/comm/external_relations/mine/intro/strat05_07.htm

European Policy Center (EPC). Iran's Nuclear Programme-a transatlantic assessment, 2006. Available online from http://www.theepc.be/en/er.asp?TYP=ER\&LV=293\&see=y\&t=2\&PG=ER/EN/de tail\&l=\&AI=582

European Union Institute for Security Studies (EU-ISS). Newsletters no. 19: dialogue with Iran- the EU Way out of the Impasse, 2006. Available online from http://www.iss-eu.org/newslttr/n19.pdf

Financial Times. EU Will Continue Nuclear Talks with Tehran, 2006 Available online $\quad$ from http://www.ft.com/cms/s/90a61514-3853-11db-ae2c-0000779e2340.html

------. US Says Iran Must Face Consequences, 2006 Available online from http://www.ft.com/cms/s/95b60d46-3909-11db-a21d-0000779e2340.html

Goodin Robert and Charles Tilly. Contextual Political Analysis. Oxford: Oxford University Press, 2006 Huntington, Samuel. The Clash of Civilizations and the Remaking of World Order. New York: Simon \& Schuster, 1997

Institute for Science and International Security (ISIS). Publication-Iran: Better Carrots not Centrifuges, 2006. Available online from http://www.isis-online.org/publications/iran/iranissuebrief.pdf

International Atomic Energy Agency (IAEA). In Focus IAEA and Iran: Documents and ReportsFebruary Resolution, 2006. Available online from http://www.iaea.org/NewsCenter/Focus/IaeaIran/index.shtml

------. In Focus IAEA and Iran: Iran Safeguards Agreement, 1974. Available online from http://www.iaea.org/NewsCenter/Focus/IaeaIran/index.shtml

International Campaign to Ban Landmines (ICBL). Landmine Monitor Report: Bosnia-Landmine and UXO Problem, 2005. Available online from http://www.icbl.org/lm/2005/bosnia.html\#Heading59

------. Landmine Monitor Report: Major Findings, 2005. Available online from http://www.icbl.org/lm/2005/

------. States not Parties, 2006. Available online from http://www.icbl.org/treaty/snp

------. States Parties, 2006. Available online from http://www.icbl.org/treaty/members

International Institution for Strategic Studies (IISS). Iran's Strategic Weapons Programmes-a net assessment, 2005. Available online from http://www.iiss.org/index.asp?pgid=5498

Lenarcic, David. Knight-Errant? Canada and the Crusade to Ban Anti-Personnel Land Mines. Toronto: Irwin Publishing, 1998

Long, David. “The European Union and the Ottawa Process to Ban on Landmines." Journal of European Public Policy. 9, no. 3 (June 2002)

Matthew, Richard, Bryan McDonald, and Kenneth Rutherford. Landmines and Human Security: International Politics and War's Hidden Legacy. New York: State University Press, 2004

Maxwell, Cameron et al. To Walk without Fear: The Global Movement to Ban Landmines. New York: Oxford University Press, 1998

McGrath, Rae. Landmines and Unexploded Ordnance: A Resource Book. London: Pluto Press, 2000 
New Threat Initiative (NIT). Issue and analysis: Iran, 2004. Available online from http://www.nti.org/e_research/e3_59a.html

------. Nuclear Chronology: Iran, 2004. Available online from http://www.nti.org/e_research/profiles/Iran/1825_4398.html

------. Nuclear Weapons: G8 Declaration on Iran Nuclear Program, 2003. Available online from http://www.nti.org/d_newswire/issues/newswires/2003_6_3.html

Nye, Joseph. Soft Power: The Means to Success in World Politics. New York: Public Affairs, 2005

Resnick, Philip. The European Roots of Canadian Identity. Peterborough: Broadview Press, 2005

Risse-Kappen, Thomas. "Ideas do not Float Freely: Transnational Coalitions, Domestic Structures, and the End of the Cold War." International Organization. 48, no. 2 (Spring 1994): 185-214

Strategic Policy Consulting (SPC). Biography: Alireza Jafarzadeh, 2005. Available online from http://www.spcwashington.com/index.php?option=com_content\&task=view\&id= $\underline{32 \& \text { Itemid }=43}$

United Nations Department of Disarmament (UNDD). Peace and Security through Disarmament, 2006. Available online from http://disarmament.un.org

United Nations Mine Action Service (UNMAS). Video: If There Were Landmines Here, Would You Stand for Them Anywhere?, 2006. Available online from http://www.stoplandmines.org/slm/index.html

Wendt, Alexander. Social Theory of International Politics. Cambridge: Cambridge University Press, 1999 